coverage of abstracts within its field of interest, while the Institute of Fuel is considering the possibility of issuing collected abstracts of fuel literature. The Department had had arrangements with abstract ing organizations which do not make their abstracts directly available to the general public, whereby abstracts of fuel literature could be published in Fuel Abstracts, and there was no reason to suppose that similar arrangements could not be made by any other organization which publishes collected abstracts of fuel literature.

\section{International Geophysical Year: Meeting in Moscow}

THe fifth meeting of the Special Committee (C.S.A.G.I.) of the International Geophysical Year is being held during July 29-August 9 in the Moscow State University. The meeting is reviewing the achievements of the International Geophysical Year since its commencement on July 1, 1957, and also the scheme now in operation for the deposition and exchange of results between the three data centres set up for each of the International Geophysical Year disciplines. During the course of the meeting there will be many discussions of a technical nature concerning preliminary results, and in addition there will be a symposium lasting several days concerning the rocket and artificial Earth satellite programme. A meeting of the Special Committee for Antarctic Research set up by the International Council of Scientific Unions is to consider research programmes in the Antarctic region after the closing of the International Geophysical Year programme on December 31, 1958 .

\section{Tax Concessions on Subscriptions to Learned Societies}

WHEN the tax concessions to individuals on their fees and subscriptions to learned societies and professional bodies, contained in the Finance Bill, were debated in the House of Commons on July 17, objections were raised to the limitation of the concession to bodies which were "not of a mainly local character". Mr. J. E. S. Simon, Financial Secretary to the Treasury, explained that the Inland Revenue had already to examine the claims of some 3,000 national societies and to extend it to all the local bodies would involve an administrative task in which the benefit to individuals would be out of all pro. portion to the expense involved. He fully appreciated the claims of many local societies but insisted that the relief to the individual tax-payer had to be balanced against the cost to the general body of taxpayers. He undertook, however, to put the views expressed before the Chancellor of the Exchequer. Mr. Simon also said that it was not a condition of relief that the employer should stipulate membership of a professional body; it was sufficient that the registration should be a condition for the performance of the claimant's duties. The views of the employer were no longer relevant. $\mathrm{He}$ also added that the clause would not be construed narrowly by the Inland Revenue, but in a common-sense way, with a desire to help professional men who could bring themselves fairly within its terms.

\section{Journal of Nuclear Energy}

IT has been announced that the Journal of Nuclear Energy is shortly to be issued in two parts $(A$ and $B$ ) dealing respectively with basic reactor science and reactor technology. Part $A$ will continue to be published monthly with little alteration and will consist of papers dealing with the scientific, biological and economic aspects of nuclear energy. Part $B$ will be published quarterly and the first issue will appear in time for the Second Geneva Conference. It will be devoted to technological subjects contributing to the development of nuclear energy for peaceful purposes and will contain papers on mathematics (including computing for design purposes) ; applied physies ; fuel processing and plant criticality; heat transfer ; fuel element design and fabrication; and other scientific aspects of the construction and operation of nuclear reactors. The editors direct attention to three important charac. teristics of Part $B$ : the international character of the journal; the high scientific and professional standard; and the short publication time. Both parts of the journal will contain translations of relevant papers published in the Russian journal of atomic energy, Atomnaya Energiya.

\section{Progress in Rubber Technology}

The current annual report on the "Progress of Rubber Technology" (edited by Dr. T. J. Drakeley, Pp. $x i+134$. Cambridge : W. Heffer and Sons, Ltd., 1958. 25s.), issued by the Institution of the Rubber Industry, gives a brief but reasonably detailed review of developments up to the end of 1957. All aspects of the industry, scientific, technical and economic, are included, and the arrangement in the form of short chapters on specific topics makes for easy reading and quick reference. The subject-matter is not limited to rubbers, but includes materials, such as fibres and plastics, which are used either in association with rubbers or as alternatives to them. Every branch of the industry, including tyres, belting, cables, footwear, cellular rubber, flooring and roads, is covered, and other chapters deal with subjects of more general scientific interest, though these form only a small proportion of the whole. The main value of this publication is that it enables the reader to keep in touch with developments outside his own speciality, and to obtain a quick appreciation of general trends in the industry. Foremost among these is that--in spite of the continued advance of synthetic rubbers and of materials designed to satisfy particular technical requirements- the total demand is expanding at such a rate that the market for natural rubber has remained remarkably stable, and new planting is in progress in various parts of the world. There appears also to be a lively development of scientific interest in new ways of using natural rubber, particularly in conjunction with other polymers, to meet the threat of competition from the synthetics.

\section{New Floristic Studies}

TrE physiography of the vast and interesting region comprising the Canadian Arctic Archipelago has recently been described in a publication issued by the National Museum of Canada, "Illustrated Flora of the Canadian Arctic Archipelago", by A. E. Porsild (National Museum of Canada, Bulletin No. 146 : Biological Series No. 50. Pp. iii + 209. Ottawa: Queen's Printer, 1957. 2 dollars). The Bulletin also deals with the soils and plant habitats of the region; and numerous illustrations, species distribution maps and keys are provided. In all, some 340 species and major geographical races of flowering plants and pteridophytes are described. The author records that, in this and other floristic studies of the region 